Scholtens, Murkje. Études médico-psychologiques sur Pascal. Haarlem (Pays-Bas): Enschedé et Zonen, I958. 199 p. 8 pls.

Smits, Luchesius. Saint Augustin dans l'auvre de Jean Calvin. Tome II: Tables des références augustiniennes. Assen (Pays-Bas): Van Gorcum. 1958. 295 p. I9, 5o fl. Rel. $22 \mathrm{fl}$.

Spinoza, Benedictus de. Selections. (Modern Students' Library.) New York: Scribner, 1958. 2nd ed. 479 p. Pap. \$I.

Stange, Carl. Die Anfänge der Theologie Luthers. Berlin: Topelmann, 1957. 6I S. 6.80.

Thomas à Kempis. Imitation of Christ. New trans. with an introd. by George F. Maine. London: Collins, I957. 280 p. $4 / 6 ; 5 / 6$; in leather, 10/6. (Under title Of the initation of Christ, New York: Nelson. 286 p. \$1.25.)
Van Asscldonk, Ant. Franciscus Vaes van Tongeren, stichter der kloosterbiblotheck van Kolen. 1499-1550. Met een voorwoord van G. I. Lieftinck. Diest: Lichtland, $1958.232 \mathrm{blz}$.

Vasella, Oskar. Reform und Reformation in der Schweiz. Zür Würdigung der Anfange der Glaubenskrise. MünsterWestfalen: Aschendorffsche Verl., 1958. 71 S. sfr. 5.20.

Vincelot, Mag. Jean de la Croix, l'ange qui fut homme. Paris: Letouzey et Ané, I959. $160 \mathrm{p} .350 \mathrm{f}$.

Westfall, Richard S. Science and religion in 17th-century England. New Haven: Yale U Press, I958. 235 P. \$4.50. (Oxford. 36/-.)

Wolff, Hans M. Spinozas Ethik. Ein krit. Einf. München: Lehnen, 1958. r28 S. 2.80 .

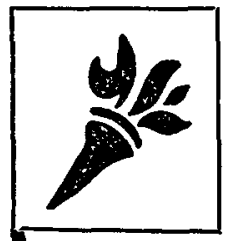

\title{
HARPER TORCHBOOKS
}

\section{LIBRARY-SIZE PAPERBACKS: A Selection}

EDWIN HATCH: The Influence of Greek Ideas on Christianity. Intro. and biblio. by F. C. Grant. 400 pp.

JOHAN HUIZINGA: Erasmus and the Age of Reformation. 32 illus. $280 \mathrm{pp.}$ $\mathrm{TB} / 19 \$ 1.50$

G. G. COULTON: Medieval Faith and Symbolism, Part I of Art and the Reformation. 88 illus. $464 \mathrm{pp}$.

$\mathrm{TB} / 25 \$ 1.85$

G. G. COULTON: The Fate of Medieval Art in the Renaissance and Reformation, Part II of Art and the Reformation. 27 illus. 256 pp.

TB $/ 26 \$ 1.35$

ALEXANDRE KOYRE: From the Closed World to the Infinite Universe. $320 \mathrm{pp}$.

$\mathrm{TB} / 31 \$ 1.60$

JACOB BURCKHARDT: The Civilization of the Renaissance in Italy. Intro. by Benjamin Nelson and Charles Trinkaus.

Volume I 131 illus. 304 pp. TB $/ 40 \$ 1.35$

Volume II 111 illus. $256 \mathrm{pp}$. TB $/ 41$ \$1.35

EMILE MÂLE: The Gothic Image: Religious Art in France of the Thirteenth Century. 190 illus. 439 pp.

TB $/ 44 \$ 1.95$

HENRY OSBORN TAYLOR: The Emergence of Christian Culture in the West. The Classical Heritage of the Middle Ages. Intro. and biblio. by Kenneth M. Setton. 399 pp.

$\mathrm{TB} / 4^{8} \$ 1.75$

At your bookseller HARPER \& BROTHERS, N. Y. 16 


\title{
From Doubleday Anchor Books The Book of the Courtier
}

\author{
by CASTIGLIONE
}

in a new translation by Charles $S$. Singleton

$T$

HIS perennially fresh and vigorous study of Renaissance etiquette remains our most vivid account of manners and morals in 16 thcentury Italian court life. Recent studies have made it possible for the translator to follow the original text more faithfully than other modern translations. Complete and unexpurgated, this edition includes 32 pages of intriguing pictures of personages and scenes, edited by Edgar deN. Mayhew.

At all booksellers

SEND FOR COMPLETE LIST TO

DOUBLEDAY ANCHOR BOOKS

575 Madison Avenue, New York 22

\section{HENRY VAUGHAN}

\section{Experience and The Tradition}

by Ross Garner 'Ross Garner's Henry Vaughan is an informed, thoughtful, and provocative book. Whatever particular queries a reader may have, the study as a whole is, first, a vigorous and acute corrective to the conventional Hermetic approach of nearly all modern criticism, and, secondly, a positive interpretation of an individual and elusive but thoroughly Christian poet. The book is both broadly based and minutely exegetical, and it has value for any student of seventeenthcentury religious poetry and thought.'-DOUGLAS BUSH $\$ 5.00$

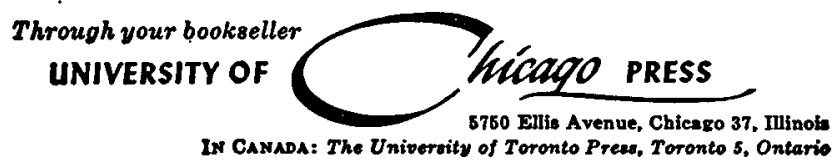




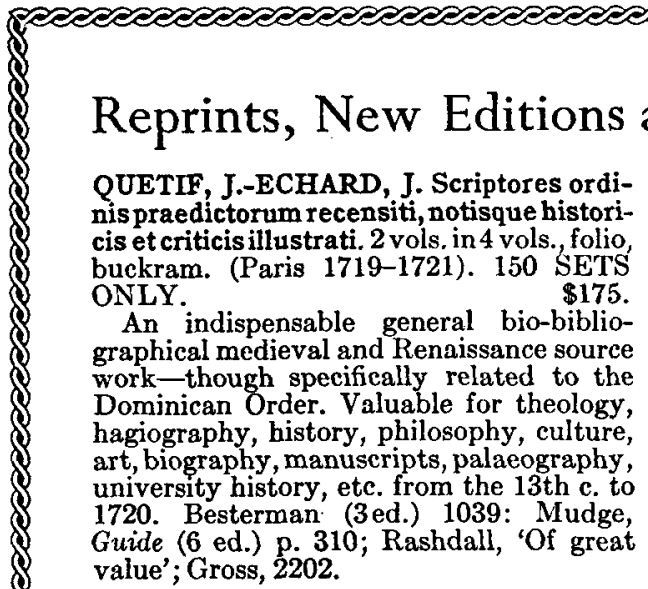

FLICK, A. C. The rise of the mediaeval church and its influence on the civilization of Western Europe from the first to the 13th century. 637 pp. buckram. (1901) NY 1959.

Shaw List: p. 595; Pactow, prime number 428. Standard. 'The (church) institution as a part of civilization is traced rather than the growth of dogma ...' Watson, in: $A n$ nals, 35:719. 'Testimony that history of the church demands a different perspective... By virtue of this aim gains its interest and significance... No other book covers the field in this way:' Am. Church Hist., 15:641.

OMAN, SIR CHARLES. The history of the art of war in the Middle Ages. 2nd rev. ed., 2 vols., maps, illus., $1000+$ pp. NY 1959.

On Colorado List; Gross, 14; Paetow, p. 149; Camb. Med., passim; Vasiliev, p. 778; Dutcher, H511; 'The only authoritative English work ... Describes the history of warfare ... military tradition ... infantry '...gunpowder.'

EISNER, SIGMUND. A tale of wonder: a source study of (Chaucer's) 'The Wife of Bath's Tale'. 148 pp., cloth, bibliog. $\$ 6$ A major contribution to Chaucerian and Arthurian studies as well as in medieval romance. Re-examination of the theme of the 'loathly lady' in medieval lit. Places Chaucer's work in proper relationship to its analogues. Indispensable adjunct to, probably superseding, Maynadier (1901).

SCHOEPPERLE, GERTRUDE. Tristan and Isolt, a study of the sources of the romance. 2 vols. New edition with bibliography by R. S. Loomis. NY 1959. $\$ 25$ 'It remains after forty years the main study on Tristan' Roach (1959). 'Basic'; 'Fine scholarship' Utley (1958). 'Tine study' J. D. Bruce. 'Index of themes and motifs is most useful for studies of medieval fiction outside the romance of 'Tristan' R. S. Loomis (1959). New edition enhanced by Loomis' valuable classified bibliography and lengthy essay.

PATON, LUCY ALLEN. Studies in Arthurian romance. New ed. with bibliog. by R. S. Loomis. NY 1959.

$\$ 9.50$ 'Invaluable' J. D. Bruce, I, 80; 'Without a peer . . ' Nitze, in M.L.N. 14:82; 'Basic' Utley (1958).

HIBBARD, LAURA A. Mediaeval romance in England: a study of the sources and analogues of the non-cyclic metrical romances. New ed. with bibliog. by the author. NY 1959.

$\$ 9.50$

Invaluable adjunct to Wells, Manual of Writings in Middle English, but within its scope more useful in that she 'examines in greater detail and gives fuller information' on the thirty-uine romances treated. Year's Work in Eng. 5:91. 'Careful compilation. Should supersede other bibliographical collections [non-cyclic romances].' (ibid.)

DIEHL, CH. Etudes sur l'administration byzantine dans l'Exarchat de Ravenne (568-751). 440 pp., buckram. (P. 1888) NY 1959.

$\$ 17.50$

Rome itself was part of the Exarchat. 'Great publication'; 'Standard' P. Charanis, in: Diehl, Byzantium (1957). 'Never ... have the methods of the imperial government been so well analyzed' L. Brehier, in: Hist. et Historiens II, 764; Vasiliev, p. 748.

DIEHL, CH. Justinien et la civilization byzantine au VIe siecle. 2 vols. 695 pp., 133 illus. (P 1901) 1959.

$\$ 28.50$

'Epoch-making in itself' L. Brehier, in Hist. et Historiens II, 666. 'Ouvrage remarquable' ibid., p. 674. 'The most comprehensive .... account' Charanis, 'Comprehensive research' Ostrogorsky, p. 8.

DIEHL, CH. L'Afrique byzantine. 2 vols., 668 pp., 89 illus., maps, buckram. (P 1896) 1959.

$\$ 28.50$

'Great book'; 'Standard' Charanis (1957);

'Capital work' ibid., p. 323. 'Vivid ... Most accurate scholarship' Ostrogorsky, p. 8; Vasiliev, p. 748.

At your bookseller or

\title{
BURT FRANKLIN, PUBLISHER
}

\author{
SI 4 WEST II3 STREET, NEW YORK 25 , NEW YORK
}

Complete catalogue of publications on request 